\title{
HUBUNGAN ANTARA PENYAKIT JANTUNG BAWAAN DENGAN KECUKUPAN ASUPAN MAKANAN
}

\author{
Mardiati ${ }^{1}$, Tiangsa Sembiring ${ }^{2},{\text { Muhammad } \mathrm{Ali}^{3} \text {, Tri Faranita }}^{4}$, Winra Pratita ${ }^{5}$ \\ ${ }^{1}$ Bagian Ilmu Kesehatan Anak, Fakultas Kedokteran Universitas Malikussaleh \\ 2,3,4,5 Departemen Ilmu Kesehatan Anak, Fakultas Kedokteran Universitas Sumatera \\ Corresponding Author: mardiati8143@yahoo.co.id
}

\begin{abstract}
Abstrak
Gizi merupakan hal penting untuk memastikan energi yang adekuat untuk metabolisme basal, pertumbuhan, dan aktivitas fisik. Bayi dan anak dengan penyakit jantung bawaan (PJB) memiliki risiko yang signifikan mengalami kekurangan energi karena meningkatnya pengeluaran energi dan asupan makanan yang tidak memadai. Tujuan penelitian ini adalah untuk mengetahui hubungan antara penyakit jantung bawaan dengan kecukupan asupan makanan terutama energi dan protein. Penelitian ini menggunakan desain cross-sectional yang dilakukan pada bulan Mei sampai Juni 2015 di Rumah Sakit Umum Adam Malik, Medan. Subjek dibagi menjadi PJB dan tanpa PJB. Asupan makanan dihitung berdasarkan makanan yang dikonsumsi selama tiga hari dan kecukupan energi dan protein dihitung menggunakan program Nutrisurvey. Data dianalisis dengan chi square untuk melihat hubungan PJB dengan asupan makanan. Untuk menilai faktor-faktor yang mempengaruhi asupan makanan pada PJB digunakan uji bivariat yang selanjutnya dilakukan analisis multivariat. Hasilnya adalah dari 80 anak yang memenuhi kriteria, 40 anak dengan PJB dan 40 anak tanpa PJB. Terdapat hubungan yang signifikan antara PJB dengan asupan energi dengan risiko terjadinya asupan energi tidak cukup pada PJB adalah 1.824 kali dengan 95\% IK 1.226 - 2.713 dibandingkan tanpa PJB. Terdapat hubungan yang signifikan antara PJB dan asupan protein dengan risiko terjadinya asupan protein tidak cukup pada PJB adalah 3.5 kali dengan 95\% IK 1.823-6.719 dibandingkan tanpa PJB. Tidak terdapat pengaruh usia, jenis PJB, lama sakit dan status gizi terhadap asupan energi dan protein pada anak PJB. Kesimpulannya terdapat hubungan yang signifikan antara penyakit jantung bawaan dengan kecukupan asupan makanan terutama energi dan protein.
\end{abstract}

Kata kunci : asupan makanan; energi; penyakit jantung bawaan; protein. 


\title{
ASSOCIATION BETWEEN CONGENITAL HEART DISEASE AND FOOD INTAKE
}

\begin{abstract}
Nutrition is very essential for ensuring adequate energy for basal metabolism, growth, and physical activity. Infants and children with congenital heart disease (CHD) are at significant risk for developing deficiency of energy imbalance due to increased expenditure of energy and inadequate food intake. The intake of calories in CHD usually below the recommended levels. The objective of this study is to determine the association between congenital heart disease and food intake especially energy and protein. This is a cross-sectional study was conducted on May to June 2015 in H. Adam Malik General Hospital, Medan. Subjects were divided into children with CHD and without CHD. The intake of food was calculated based on the food consumed during three days and the energy and protein were calculated using Nutrisurvey software. Association between CHD and food intake was assessed using chi square test. The results are, from the 80 children who met the criteria, 40 children were with CHD and 40 children were without CHD. There were significant association between CHD with energy intake and $\mathrm{CHD}$ with protein intake, $[\mathrm{P}=0.001 ; \mathrm{PR}=1.824 ; 95 \% \mathrm{CI}(1.226$ 2.713)] and [ $\mathrm{P}=0.001 ; \mathrm{PR}=3.500 ; 95 \% \mathrm{CI}$ (1.823-6.719)], respectively. There were no association between food intake with age, type of CHD, duration of illness, nutritional status and severity of the cardiac defect in CHD. There was a significant association between congenital heart disease and food intake especially energy and protein.
\end{abstract}

Keywords : Congenital heart disease; energy; food intake; protein 


\section{PENDAHULUAN}

Penyakit jantung bawaan (PJB) merupakan kelainan bawaan yang sering dijumpai pada anak. ${ }^{1}$ Insiden PJB dilaporkan sebanyak 1\% di Amerika Serikat dan $0.8 \%$ di negara-negara Eropa. ${ }^{2,3}$ Studi di negara maju dan di negara berkembang termasuk Indonesia menunjukkan bahwa insiden PJB berkisar di antara 6 sampai 10 per 1000 kelahiran hidup, dengan rata-rata 8 per 1000 kelahiran hidup. ${ }^{4}$

Penyakit jantung bawaan secara klinis diklasifikasikan atas PJB asianotik dan sianotik. ${ }^{5}$ Prevalensi gangguan gizi dan gagal tumbuh pada anak dengan penyakit jantung bawaan sangat tinggi. ${ }^{6,7}$ Penelitian di Nigeria pada anak PJB didapatkan prevalensi gangguan gizi anak dengan penyakit jantung bawaan adalah $90.4 \%$ dibandingkan anak sehat tanpa PJB sebesar $21.1 \%$, dengan prevalensi gangguan gizi akut pada PJB asianotik 58.3\% dan gangguan gizi kronis pada PJB sianotik $68.0 \%{ }^{8}$ Penelitian di Jakarta pada anak PJB di dapatkan prevalensi kekurangan gizi sebesar $51.1 \%$ dengan $22.3 \%$ diantaranya adalah gizi buruk. ${ }^{9}$

Penelitian di Brazil pada anak PJB yang menilai asupan makanan yang dihitung selama tiga hari didapatkan asupan kalori per kilogram berat badan, protein harian, natrium dan vitamin A adalah sesuai tingkat yang direkomendasikan. Namun, asupan kalori harian, lemak, serat, kalium dan besi berada di bawah tingkat yang direkomendasikan dan asupan protein per kilogram berat badan, karbohidrat, kalsium dan vitamin $\mathrm{C}$ adalah di atas tingkat yang direkomendasikan. ${ }^{10}$ Gizi yang adekuat merupakan hal yang sangat penting bagi bayi dan anak dengan penyakit jantung bawaan untuk mempertahankan berat badan dan tinggi badan dari waktu ke waktu. ${ }^{11}$

Tujuan dari penelitian ini adalah untuk mengetahui hubungan antara penyakit jantung bawaan dengan kecukupan asupan makanan terutama energi dan protein.

\section{METODE PENELITIAN}

Penelitian ini bersifat cross sectional yang dilakukan di Poliklinik rawat jalan Kardiologi Anak RSUP Haji Adam Malik Medan. Penelitian dilaksanakan pada bulan Mei sampai Juni 2015. Kriteria inklusi adalah Anak umur 0 sampai 5 tahun yang menderita penyakit jantung bawaan dan tanpa penyakit jantung bawaan yang telah dilakukan echocariografi. Anak dieksklusikan bila mempunyai kelainan bawaan lain, 
penyakit keganasan serta penyakit kronis, dijumpai edema dan asites serta telah menjalani operasi koreksi.

Subyek dikumpulkan secara consecutive sampling. Data diperoleh dari wawancara dan kuisioner. Anak yang menderita penyakit jantung bawaan dimasukkan sebagai kelompok kasus, sedangkan anak normal disesuaikan umur dan jenis kelaminnya dimasukkan sebagai kelompok kontrol.

Dilakukan anamnesis kepada orang tua masing-masing anak mengenai asupan makanan melalui food recall 24 jam selama 3 hari (termasuk didalamnya 1 hari libur) dengan bantuan food model dan dilakukan perhitungan kalori rata-rata dengan program Nutrisurvey. Asupan makanan rata-rata cukup bila $\geq 80 \%$ dari kebutuhan berdasarkan angka kecukupan gizi (AKG) tahun 2012 dan asupan makanan rata-rata tidak cukup bila $<80 \%$ dari kebutuhan. Penelitian ini disetujui oleh Komite Etik Penelitian Fakultas Kedokteran Universitas Sumatera Utara.

Data dianalisis dengan menggunakan uji chi square untuk menilai hubungan antara penyakit jantung bawaan dengan asupan makanan. Pengolahan data dengan menggunakan SPSS dengan tingkat kemaknaan bila $\mathrm{P}<0.05$ dan tingkat kepercayaan dengan Interval kepercayaan 95\%.

\section{HASIL PENELITIAN}

Selama periode penelitian diperoleh sampel 80 anak yang memenuhi kriteria inklusi terdiri dari 40 orang dari masing-masing kelompok. Hubungan antara status penyakit jantung dengan asupan energi ditunjukkan pada Tabel 1.

Tabel 1. Hubungan status penyakit jantung dengan asupan energi

\begin{tabular}{|c|c|c|c|c|c|c|}
\hline \multirow{2}{*}{$\begin{array}{c}\text { Status } \\
\text { Penyakit } \\
\text { Jantung }\end{array}$} & \multicolumn{2}{|c|}{ Asupan Energi } & \multirow{2}{*}{$\mathbf{P}$} & \multirow{2}{*}{$\mathbf{P R}$} & \multirow{2}{*}{\multicolumn{2}{|c|}{$\begin{array}{c}\text { IK } \\
95 \%\end{array}$}} \\
\hline & Cukup & Tidak Cukup & & & & \\
\hline PJB & 9 & 31 & \multirow{2}{*}{$0.001 *$} & \multirow{2}{*}{1.824} & \multirow{2}{*}{1.226} & \multirow{2}{*}{2.713} \\
\hline Tanpa PJB & 23 & 17 & & & & \\
\hline
\end{tabular}

*Chi square

Dari hasil perhitungan asupan makanan berdasarkan AKG memperlihatkan bahwa terdapat hubungan yang signifikan antara penyakit jantung bawaan dengan 
asupan energi dengan $\mathrm{P}<0.05$, dapat dilihat pada tabel 1. Pada PJB didapati lebih banyak asupan energi tidak cukup 31 anak sedangkan pada tanpa PJB dijumpai 17 anak dengan asupan energi tidak cukup. Risiko terjadinya asupan energi tidak cukup pada PJB adalah 1.824 kali dengan 95\% IK 1.226 - 2.713 dibandingkan anak tanpa PJB.

Tabel 2. Hubungan status penyakit jantung dengan asupan protein

\begin{tabular}{|c|c|c|c|c|c|c|}
\hline \multirow{2}{*}{$\begin{array}{c}\text { Status } \\
\text { Penyakit } \\
\text { Jantung }\end{array}$} & \multicolumn{2}{|c|}{ Asupan Energi } & \multirow{2}{*}{$\mathbf{P}$} & \multirow{2}{*}{ PR } & \multirow{2}{*}{\multicolumn{2}{|c|}{$\begin{array}{c}\text { IK } \\
95 \%\end{array}$}} \\
\hline & Cukup & Tidak Cukup & & & & \\
\hline PJB & 12 & 28 & \multirow{2}{*}{$0.001 *$} & \multirow{2}{*}{3.500} & \multirow{2}{*}{1.226} & \multirow{2}{*}{2.713} \\
\hline Tanpa PJB & 32 & 8 & & & & \\
\hline
\end{tabular}

*Chi square

Hasil perhitungan asupan makanan berdasarkan AKG memperlihatkan bahwa terdapat hubungan yang signifikan antara penyakit jantung bawaan dengan asupan protein dengan $\mathrm{P}<0.05$, terlihat pada tabel 2. Pada PJB didapati lebih banyak asupan protein tidak cukup yaitu sebanyak 28 anak sedangkan pada tanpa PJB dijumpai 8 anak asupan protein tidak cukup. Risiko terjadinya asupan protein tidak cukup pada PJB adalah 3.5 kali dengan 95\% IK 1.823-6.719 dibandingkan anak tanpa PJB.

\section{PEMBAHASAN}

Anak dengan penyakit jantung bawaan memiliki prevalensi yang tinggi mengalami kesulitan dalam hal makan dan gangguan gizi. ${ }^{12}$ Prevalensi gangguan gizi akut pada anak yang dirawat di rumah sakit masih diperkirakan tinggi, tetapi data mengenai status gizi saat masuk rumah sakit masih sangat jarang. ${ }^{13}$ Data dari negara berkembang memperlihatkan prevalensi gangguan gizi penderita dengan PJB sebelum dioperasi mencapai $45 \%{ }^{14}$ Studi yang dilakukan di Jakarta memperlihatkan prevalensi kurang gizi $51.1 \%$ dan malnutrisi berat $22.3 \%$ pada anak PJB, dengan prevalensi gagal tumbuh lebih tinggi daripada masalah gangguan gizi. ${ }^{9}$ Gangguan gizi pada anak dengan PJB disebabkan oleh banyak faktor dan timbul dikarenakan kebutuhan dan kehilangan energi lebih besar daripada asupan makanan. ${ }^{7}$ Etiologi dari gangguan gizi pada anak dengan PJB secara umum dapat dikelompokkan menjadi tiga kategori: asupan makanan yang 
tidak cukup adekuat, penyerapan dan pemanfaatan tidak efisien, serta kebutuhan energi yang meningkat. ${ }^{10,15}$

Penelitian di Swedia melaporkan bahwa asupan energi pada anak PJB dengan usia 6 sampai 12 bulan tidak cukup atau berada dibawah AKG, tetapi asupan protein berada diatas $\mathrm{AKG} .{ }^{16}$ Pada penelitian ini didapati bahwa asupan energi dijumpai tidak cukup dan berada dibawah anjuran AKG sehingga menunjukkan hubungan signifikan antara PJB dan asupan energi, sedangkan asupan protein juga dijumpai tidak cukup dan berada dibawah AKG pada anak dengan PJB yang menunjukkan hubungan yang signifikan antara PJB dengan asupan protein.

Penelitian sebelumnya mengenai asupan energi dan protein pada anak dengan penyakit jantung bawaan di Semarang, hasilnya didapatkan bahwa perhitungan masukan energi dan protein yang dihitung dari food recall satu kali dalam 24 jam didapati lebih dari 50\% anak PJB memenuhi asupan energi dan protein sesuai RDA. ${ }^{17}$ Pada penelitian ini dilakukan food recall 24 jam selama 3 hari dengan menilai asupan energi dan protein berdasarkan AKG didapati 31 anak dengan asupan energi tidak cukup dan 28 anak asupan protein tidak cukup.

Penelitian di Nigeria terhadap anak usia prasekolah, usia 2-5 tahun didapati asupan energi dan protein yang tidak adekuat dan berada di bawah level yang direkomendasikan. ${ }^{18}$ Penelitian di Australia pada anak usia 1 sampai 5 tahun didapati bahwa asupan energi dan protein cukup adekuat. ${ }^{19}$ Pada penelitian ini usia anak 0-5 tahun dengan PJB dan tanpa PJB didapati asupan energi dan protein yang tidak cukup lebih banyak pada anak PJB.

\section{KESIMPULAN}

Terdapat hubungan antara penyakit jantung bawaan dengan kecukupan asupan makanan terutama energi dan protein. 


\section{DAFTAR PUSTAKA}

1. Clarke E, Kumar MR. Evaluation of suspected congenital heart disease in the neonatal period. J.Cupe 2005; 15:523-31.

2. Centers for Disease Control and Prevention MMWR. Racial differences by gestational age in neonatal deaths attributable to congenital heart defects-United States 2003-2006. 2010; 59:1208-11.

3. Dolk H, Loane M, Garne E. Congenital heart defects in Europe: prevalence and perinatal mortality, 2000 to 2005. Circ J 2011; 123:841-49.

4. Bernstein D. Epidemiology and genetic basis of congenital heart disease. Dalam: Behrman RE, Kliegman RM, Jenson HB, Stanton BF, penyunting. Nelson textbook of pediatrics. Edisi ke-19. Philadelphia: Saunders 2011. h.1549-610.

5. Nousi D, Christou A. Factors affecting the quality of life in children with congenital heart disease. Health Science Journal 2010; 4(2):94-100.

6. Benzecry SG, Leite HP, Oliveira FC, Santana e Meneses JF, Carvalho WB, Silva CM. Interdisciplinary approach improves nutritional status of children with heart diseases. J.Nut 2008; 669-74.

7. Hagau N, Culcitchi C. Nutritional support in children with congenital heart disease. Nutr Ther Metab 2010; 28:172-84.

8. Okoromah CAN, Ekure EN, Esi FEAL, Okunowo WO, Tijani BO, Okeiyi JC. Prevalence, profile and predictors of malnutrition in children with congenital heart defects; a case - control observational study. Arch Dis Child 2011; 96:354-60.

9. Sjarif DR, Anggiawan SL, Putra ST, Djer MM. Anthropometric profiles of children with congenital heart disease. Med J Indones 2011; 20:40-5.

10. Vieira TCL, Trigo M, Alonso RR, Ribeiro RHC, Cardoso MRA, Cardoso ACA, et al. Assesment of food intake in infants between 0 and 24 months with congenital heart disease. Arq Bras Cardiol 2007; 89:197-202.

11. Steltzer M. Heart disease. Dalam: Koletzko B, penyunting. Pediatric nutrition in practice. Basel: Karger 2008.h.229-33.

12. Pierre AS, Khattra P, Johnson M, Cender L, Manzano S, Holsti L. Content validation of the infant malnutrition and feeding checklist for congenital heart disease: a tool to identify risk of malnutrition and feeding difficulties in infants with congenital heart disease. Journal of Pediatric Nursing 2010; 25:367-74. 
13. Joeston KFM, Hulst JM. Prevalence of malnutrition in pediatric hospital patients. Curr Opin Pediatr 2008; 20:590-6.

14. Vaidyanathan B, Roth SJ, Gauvreau K, Shivaprakasha K, Rao SG, Kumar RK. Somatic growth after ventricular septal defect in malnourished infants. J Pediatr 2006;149:205-9.

15. Roman B. Nourishing little hearts: nutritional implications for congenital heart defects. Dalam: Parrish CR, penyunting. Nutrition issues in gastroenterology. Virginia: Practical Gastroenterology 2011. h.11-34.

16. Hansson L, Ohlund I, Lind T, Blicks Stecksen C, Rydberg A. Dietary intake in infants with complex congenital heart disease : a case control study on macro and micronutrient intake, meal frequency and growth. J Hum Nutr Diet 2014; 1-8.

17. Wisnuwardhana M. Manfaat pemberian diet tambahan terhadap pertumbuhan pada anak dengan penyakit jantung bawaan asianotik. Tesis pada S2 Magister Ilmu Biomedik Program Pasca Sarjana Universitas Diponegoro 2006.(tesis)

18. Okoreigwe, Chizoba F, Okeke, Chinwe E. Nutritional status of preschool children aged 2-5 years in Aguata L G A of Anambra State, Nigeria. Int.J.Nutr.metab 2009; 1:009-013.

19. Zhou SJ, Gibson RA, Gibson RS, Makrides M. Nutrient intakes and status of preschool children in Adelaide, South Australia. MJA 2012; 196:697-700. 